\title{
Meta Analisis Pengaruh Bahan Ajar FisikaTerhadap Hasil Belajar Siswa
}

\author{
Miftahurrahmi*, Miftahurrahmi, Shinta Sari Oktavia, Desnita \\ Program Studi Pendidikan Fisika, Universitas Negeri Padang \\ *Email: miftahurrahmi062@gmail.com
}

Received: 5 Juni 2021; $\quad$ Accepted: 30 Juni 2021;

DOI: http://dx.doi.org/10.29303/jpft.v7i1.2709

Published: 30 Juni 2021

\begin{abstract}
This study aims to determine the effect of physics teaching materials on student learning outcomes. The type of research used is a meta-analysis that analyzes 25 pre-existing national articles starting from 2013-2019. The data analysis technique used is to calculate the effect size for each article. Based on the results of the study, it was found that physics teaching materials had an effect on student learning outcomes. So that it is known that first, the influence of physics teaching materials on student learning outcomes from 25 articles obtained an average effect size of 1.1308 with a very high category. The effect of the two teaching materials based on education level with the highest effect size is at the junior high school level, namely 1,395 with a very high category. The third is based on the highest effect size class level in class VIII, namely 1,395 with a very high category. Fourth, based on the type of teaching materials with the highest effect size, namely 1,418 with a very high category on teaching materials. The fifth effect magnitude based on the highest learning material is found in the material for parabolic motion, circular motion and Newton's law, which is 3.29 with a high effect category. Sixth, based on the unit method, strategy, and model, the highest effect size is 2.19 with the category having a high impact on the student recap strategy.
\end{abstract}

Keywords: Meta Analysis; Teaching Materials; Learning Outcomes.

\section{PENDAHULUAN}

Tantangan pada abad ke-21 ini terutama perkembangan dunia dalam bidang pendidikan berkembang begitu pesat, karena mengharuskan sumber daya manusia untuk memiliki beberapa keterampilan yang sesuai dengan tuntutan pada abad ke-21. Menurut Global Cities Education Network Report (2012) mengatakan bahwa terdapat 5 keterampilan yang harus dimiliki oleh siswa pada abad ke-21 yaitu, kreativitas serta inovasi, berpikir kritis (critical thinking), pemecahan masalah (problem solving), pengambilan keputusan (decision making), metakognisi.

Dalam dunia pendidikan, kualitas guru dalam menyampaikan pelajaran serta informasi harus berada pada posisi teratas, karena penyampaian guru adalah suatu hal yang menjadi patokan dalam keberhasilan siswa. Informasi ataupun pelajaran yang disampaikan oleh guru sebaiknya tidak berbelit-belit, supaya informasi pelajaran yang disampaikan guru bisa dimengerti oleh siswa.

Pada pembelajaran fisika, siswa masih kesulitan dalam menghubungkan antara penerapan dalam kehidupan sehari- hari dengan yang sedang dipelajari siswa. Siswa terlalu terfokus pada penghafalan materi dari tiap pokok bahasan dalam pembelajaran. Implementasi pada kurikulum 2013 yang mendorong dan menuntut guru mata pelajaran fisika agar dapat kreatif

dalam memfasilitasi siswa selama proses pembelajaran agar dapat memahami teori beserta konsep dari pembelajaran tersebut, serta siswa mampu menerapkan konsep tersebut dalam menyelesaikan persoalan terkait mata pelajaran fisika.

Bahan ajar fisika dapat membantu guru dan siswa dalam proses pembelajaran sehingga pembelajaran lebih efektif dan efisien terutama siswa yang mengalami kesulitan dalam memahami pembelajaran fisika. Menurut Widayanti, Abdurrahman 
(2019) bahwa jenis bahan ajar berdasarkan pembelajaran terdiri dari; (1) bahan ajar yang dirancang langsung oleh guru untuk pembelajaran seperti handout,buku,lembar kerja siswa, dan modul; (2) bahan ajar yang tidak dirancang tapi dapat digunakan dalam pembelajaran seperti koran,film atau iklan.

Untuk mengukur keberhasilan dalam proses pembelajaran menggunakan bahan ajar fisika dapat dilihat dari hasil belajar siswa. Hasil itu mengarah pada suatu yang diperoleh akibat dari suatu aktivitas yang telah dilakukan, sedangkan belajar dilakukan untuk mengusahakan adanya perilaku pada individu yang belajar. Hasil belajar adalah suatu nilai ataupun apresiasi yang diperoleh siswa setelah melakukan proses pembelajaran, dan hasil belajar merupakan suatu indikator untuk pencapaian keberhasilan dalam suatu pembelajaran.

Pada saat ini, hasil belajar siswa pada pembelajaran fisika masih tergolong rendah sehingga guru masih memberikan kesempatan kepada siswa untuk memperbaiki dan memberikan remedial kepada siswa, dikarenakan penunjang dalam belajar masih kurang. Maka dari itu, diperlukannya bahan ajar fisika agar siswa dapat belajar dan mendapatkan informasi bukan hanya dari guru saja. Berdasarkan permasalahan yang telah dipaparkan, peneliti tertarik melakukan meta analisis terhadap artikel pendidikan dan penelitian tentang bahan ajar fisika. Tujuan penelitian ini adalah mengetahui pengaruh bahan ajar fisika terhadap hasil belajar siswa. Hasil meta analisis ini diharapkan dapat memberikan keseragaman pandangan atas temuan secara menyeluruh.

\section{METODE PENELITIAN}

Jenis penelitian yang digunakan adalah penelitian survey. Metode untuk penelitian survey ini yaitu menggunakan metode meta-analisis. Meta-analisis bersifat kuantitatif karena menggunakan angkaangka dan statistik yang digunakan untuk mengolah informasi dari banyak sumber yang didapat untuk penelitian ini. Tahapan tahapan dalam penelitian ini yaitu menentukan judul penelitian, mengumpulkan data melalui literatur yang berupa artikel, (3) merangkum data penelitian berupa statistik data dengan pemberian kode pada data untuk mempermudah menganalisis data menganalisis effect size dari hasil pengumpulan data penelitian, menyimpulkan hasil analisis data sesuai dengan kriteria yang telah ditentukan.

Untuk data penelitian diambil dari artikel studi penelitian yang terakreditasi Sinta, SNN, dan Jurnal Publiaksi Internasional. Instrument yang digunakan untuk mengumpulkan data pada penelitian ini yaitu berupa lembar observasi coding data (Pengkodean). Sedangkan sampel yang digunakan sebanyak 25 artikel dari tahun 2013-2019. Berikut ini pengelompokan artikel yang digunakan pada penelitian ini yaitu sebagai berikut.

Tabel 1. Identifikasi Artikel Yang igunakan Pada Penelitian

\begin{tabular}{|c|c|c|}
\hline Kode & Pengarang & Tahun \\
\hline M1 & $\begin{array}{l}\text { Mulya Suci Utari, } \\
\text { Darvina, }\end{array}$ & 2014 \\
\hline M2 & $\begin{array}{l}\text { Satriani, Rafiqah, Muh Syihab } \\
\text { Ikbal }\end{array}$ & 2018 \\
\hline M3 & $\begin{array}{l}\text { Anggreini, Syakbaniah, Yenni } \\
\text { Darvina }\end{array}$ & 2013 \\
\hline M4 & $\begin{array}{l}\text { Rozzi Prima Yeni, Masril, } \\
\text { Hidayati }\end{array}$ & 2016 \\
\hline M5 & $\begin{array}{l}\text { Nadya Mahardika, Akmam, } \\
\text { Gusnedi }\end{array}$ & 2016 \\
\hline M6 & $\begin{array}{l}\text { Maulana Aflah, } \\
\text { Kamus, Masril, }\end{array}$ & 2019 \\
\hline M7 & $\begin{array}{l}\text { Khaerul Hidayat, Amiruddin } \\
\text { Kade, Haeruddin }\end{array}$ & 2014 \\
\hline M8 & $\begin{array}{l}\text { Aryati Liskaningsih, Sifaul } \\
\text { Gummah, Intan Kusuma } \\
\text { Wardani }\end{array}$ & 2016 \\
\hline
\end{tabular}


M9 Syamsul Hakim, Wahyudi, Nti Nyoman Sri Putu Verawati

M10 Sigit Ardiansyah, Chandra Ertikanto, Undang Rosidin

M11 Andi Fatimatul Islamiyah, 2018 Satutik Rahayu, Ni Nyoman Sri Putu Verawati

M12 Wulan Pratiwi, I Wayan 2017 Darmadi, Muslimin

M13 Hira khairunnisa, Zulhendri 2018 Kamus, Murtiani

M14 Naimis Syifa Hasibbuan, Hufri 2018

M15 Rika Septia Ameliya, Zulhendri 2019

Kamus, Masri, Renol Afrizon

M16 Furkana Aulia, Djusmaina 2017 Djamas, Ramli

M17 Kadek Ayu Astiti, Yusniati H, 2018 Muh. Yusuf

M18 Liza Nellya Basviani, Amran 2014 Hasra, Zulhendri Kamus

M19 Musanni, Susilawati, Aos 2015 Santosa Hadiwijaya

M20 Widya Oktaviani, Gunawan, 2017 Sutrio

M21 Fran Surya Andi p, Yenni 2017 Darvina, Ratnawulan

M22 Fuad Tamami, Joni Rokhmat, I 2017 Wayan Gunada

M23 Ibrahim, Kosim, Gunawan 2017

M24 Lisa Herlina, Hufri 2019

M25 Rahma Diani 2016

Untuk mencari nilai effect size pada penilitian ini yaitu dapat menggunakan persamaan dengan kode Fr-1 sebagai berikut. $E S=\Delta=$

$$
\frac{\overline{X_{e}}-\overline{X_{C}}}{S_{C}}
$$

Keterangan:

ES: Effect size

$\overline{X_{e}}$ : Nilai rata-rata kelompok percobaan

$\overline{X_{C}}$ : Nilai rata-rata kelompok pembanding

$\mathrm{S}_{\mathrm{c}}$ : Simpangan baku kelompok pembanding

(Glass, 1981)

Nilai Effect Size (ES) juga dapat dihitung dengan beberapa uji statistik menggunakan turunan persamaan effect size yaitu sebagai berikut:

- Uji-Z dengan kode Fr-2
- Uji-t dengan kode Fr-3

$$
\sqrt{\frac{2 t}{n}} \operatorname{dan} E S=Z \sqrt{\frac{1}{n e}+\frac{1}{n c}}
$$

- Uji-r / korelasi dengan kode Fr-4

$E S=$

$$
\frac{\left\{2_{r}\right\}}{\{\sqrt{(1-r)}\}}
$$

(Sutrisno, 2007)

- Uji-F dengan kode Fr-5

$$
E S=F \sqrt{\frac{2}{n}}
$$

- $\quad$ Uji- $X^{2}$ dengan kode Fr-6

$$
E S=\frac{\sqrt{X^{2}}}{n}
$$

Keterangan:

$Z$ : Skor nilai uji-Z pada penelitian awal

$\mathrm{t}$ : Skor nilai test-t pada penelitian awal

$\mathrm{r}$ : Skor uji-r pada penelitian awal

F : Skor dari uji-F pada penelitian awal

$n_{e}$ : Jumlah sampel kelompok eksperimen

$n_{c}$ : Jumlah sampel kelompok control

$X^{2}$ : Skor nilai uji- $X^{2}$ pada penelitian awal

$\mathrm{n}$ : Jumlah sampel

Setelah didapatkan nilai effect size dari tiap artikel, maka untuk hasil analisisnya dapat ditentukan dengan kriteria ukuran effect size yaitu:

- Effect size $\leq 0,15$ => efek yang dapat diabaikan

- $0,15<$ effect size $\leq 0,40=>$ efek rendah

- $0,40<$ effect size $\leq 0,75=>$ efek sedang

- $0,75<$ effect size $\leq 1,10=>$ efek tinggi

- $1,10<$ effect size $\leq 1,45=>$ efek yang sangat tinggi 
- Effect size > 1,45 $\Rightarrow$ efek yang berpengaruh tinggi

(Glass, 1981)

\section{HASIL DAN PEMBAHASAN}

Dari meta analisis yang telah dilakukan dengan cara menentukan nilai dari effect size 25 artikel yang sudah didapatkan tentang bahan ajar fisika pada artikel pertama sampai artikel ke dua puluh lima (code category) dengan M1 sampai M25 yang mana artikel M1-M25 ini merupakan artikel nasional.

\section{Hasil}

Distribusi penyebaran mengenai artikel bahan ajar fisika dapat dilihat pada Tabel 2 berikut ini.

Tabel 2. Distribusi Penyebaran Data Pengaruh Bahan Ajar Fisika Terhadap Hasil Belajar

\begin{tabular}{|c|c|c|c|c|}
\hline \multicolumn{5}{|c|}{ Siswa } \\
\hline Artikel & $\begin{array}{l}\text { Jenjang } \\
\text { Pendidikan }\end{array}$ & Kelas & $\begin{array}{l}\text { Effect } \\
\text { Size }\end{array}$ & Kategori \\
\hline M1 & SMP & VIII & 2,19 & $\begin{array}{l}\text { Berpeng } \\
\text { aruh } \\
\text { Tinggi }\end{array}$ \\
\hline M2 & SMP & VIII & 0,60 & Sedang \\
\hline M3 & SMA & X & 1,90 & $\begin{array}{l}\text { Berpeng } \\
\text { aruh } \\
\text { Tinggi }\end{array}$ \\
\hline M4 & SMA & X & 1,06 & Tinggi \\
\hline M5 & SMA & X & 0,70 & Sedang \\
\hline M6 & SMA & X & 1,03 & Tinggi \\
\hline M7 & SMA & X & 1,55 & $\begin{array}{l}\text { Berpeng } \\
\text { aruh } \\
\text { Tinggi }\end{array}$ \\
\hline M8 & SMK & X & 0,87 & Tinggi \\
\hline M9 & SMA & $X$ & 0,38 & Rendah \\
\hline M10 & SMA & X & 0,30 & Rendah \\
\hline M11 & SMA & X & 0,90 & Tinggi \\
\hline M12 & SMA & X & 0,26 & Rendah \\
\hline M13 & SMA & X & 3,29 & $\begin{array}{l}\text { Berpeng } \\
\text { aruh } \\
\text { Tinggi }\end{array}$ \\
\hline M14 & SMA & X & 1,78 & $\begin{array}{l}\text { Berpeng } \\
\text { aruh } \\
\text { Tinggi }\end{array}$ \\
\hline M15 & SMA & $X$ & 2,09 & $\begin{array}{l}\text { Berpeng } \\
\text { aruh } \\
\text { Tinggi }\end{array}$ \\
\hline
\end{tabular}

\begin{tabular}{lllll}
\hline Artikel & $\begin{array}{l}\text { Jenjang } \\
\text { Pendidikan }\end{array}$ & Kelas & $\begin{array}{l}\text { Effect } \\
\text { Size }\end{array}$ & Kategori \\
\hline M16 & SMA & X & 0,60 & Sedang \\
M17 & SMA & XI & 1,05 & Tinggi \\
M18 & SMA & XI & 1,19 & $\begin{array}{l}\text { Sangat } \\
\text { Tinggi }\end{array}$ \\
& & & & Sedang \\
M19 & SMA & XI & 0,45 & XI \\
M20 & SMA & XI & 0,78 & Tinggi \\
M21 & SMA & XI & 0,86 & Tinggi \\
M22 & SMA & XI & 0,97 & Tinggi \\
M23 & SMA & XI & 0,45 & Sedang \\
M24 & SMA & XI & 1,35 & Sangat \\
& & & & Tinggi \\
M25 & SMA & XI & 1,67 & Berpeng \\
& & & & aruh \\
& & & & Tinggi \\
ES rata-rata & & & 1,130 & Tinggi \\
\hline
\end{tabular}

Dari tabel 2 didapatkan bahwa effect size tertinggi yaitu pada artikel M13, sebesar 3,29 dengan kategori berpengaruh tinggi. Sedangkan effect size terendah adalah pada artikel M12, sebesar 0,26 dengan kategori rendah. Rata-rata dari effect size tabel 2 didapatkan kategori tinggi yaitu sebesar 1,1308 .

Tabel 3. Distribusi Karakteristik Berdasarkan Tingkatan Jenjang Pendidikan

\begin{tabular}{ccccc}
\hline No. & $\begin{array}{c}\text { Jenjang } \\
\text { Pendidikan }\end{array}$ & $\begin{array}{c}\text { Jumlah } \\
\text { Penelitian }\end{array}$ & $\begin{array}{c}\text { Effect } \\
\text { Size }\end{array}$ & Kategori \\
\hline 1 & SMP & 2 & 1,395 & $\begin{array}{c}\text { Sangat } \\
\end{array}$ \\
& SMA & 22 & 1,14 & Tinggi \\
2 & SMK & 1 & 0,87 & Tinggi \\
3 & Dari tabel 3 & didapatkan bahwa effect
\end{tabular}
size tertinggi yaitu pada jenjang pendidikan SMP sebesar 1,395 dengan kategori sangat tinggi. Sedangkan effect size terendah pada jenjang pendidikan. SMK yaitu 0,87 dengan kategori tinggi.

Tabel 4. Distribusi Karakteristik Berdasarkan Tingkatan Kelas

\begin{tabular}{ccccc}
\hline No. & $\begin{array}{c}\text { Tingkatan } \\
\text { Kelas }\end{array}$ & $\begin{array}{c}\text { Jumlah } \\
\text { Penelitian }\end{array}$ & $\begin{array}{c}\text { Effect } \\
\text { Size }\end{array}$ & Kategori \\
\hline 1 & VIII & 2 & 1,395 & $\begin{array}{c}\text { Sangat } \\
\text { Tinggi }\end{array}$ \\
2 & X & 14 & 1,19 & $\begin{array}{c}\text { Sangat } \\
\text { Tinggi }\end{array}$ \\
3 & XI & 9 & 0,97 & Tinggi \\
\hline
\end{tabular}


Dari tabel 4, didapatkan bahwa effect size tertinggi pada tingkatan kelas VIII yaitu 1,395 dengan kategori sangat tinggi. Sedangkan effect size terendah pada tingkatan kelas XI yaitu 0,97 dengan kategori tinggi.

Tabel 5. Effect Size Bahan Ajar Berdasarkan Jenis Penunjang Pembelajaran

\begin{tabular}{|c|c|c|c|c|}
\hline $\begin{array}{c}\text { Jenis } \\
\text { Penunjang } \\
\text { Pembelajaran }\end{array}$ & $\begin{array}{l}\text { Kode } \\
\text { Jurnal }\end{array}$ & $\begin{array}{l}\text { Effect } \\
\text { Size }\end{array}$ & $\begin{array}{c}\text { Rata- } \\
\text { rata } \\
\text { Ukuran } \\
\text { Effect } \\
\text { Size }\end{array}$ & Kategori \\
\hline \multirow{15}{*}{ Bahan Ajar } & M1 & 2,19 & 1,418 & Sangat \\
\hline & M3 & 1,90 & & Tinggi \\
\hline & M4 & 1,06 & & \\
\hline & M5 & 0,70 & & \\
\hline & M6 & 1,03 & & \\
\hline & M7 & 1,55 & & \\
\hline & M13 & 3,29 & & \\
\hline & M14 & 1,78 & & \\
\hline & M15 & 2,09 & & \\
\hline & M17 & 1,05 & & \\
\hline & M18 & 1,19 & & \\
\hline & M19 & 0,45 & & \\
\hline & M20 & 0,78 & & \\
\hline & M21 & 0,86 & & \\
\hline & M24 & 1,35 & & \\
\hline \multirow[t]{7}{*}{ LKS / LKPD } & M2 & 0,60 & 0,83 & Tinggi \\
\hline & M8 & 0,87 & & \\
\hline & M9 & 0,38 & & \\
\hline & M11 & 0,90 & & \\
\hline & M22 & 0,97 & & \\
\hline & M23 & 0,45 & & \\
\hline & M25 & 1,67 & & \\
\hline \multirow[t]{2}{*}{ Modul } & M10 & 0,30 & 0,45 & Sedang \\
\hline & M16 & 0,60 & & \\
\hline Video & M12 & 0,26 & 0,26 & Rendah \\
\hline
\end{tabular}

Dari tabel 5 didapatkan bahwa, ratarata effect size tertinggi yaitu pada penunjang pembelajaran sebesar 1,418 dengan kategori sangat tinggi. Sedangkan effect size tertinggi dari seluruh artikel yaitu pada artikel M13 sebesar 3,29 dengan kategori berpengaruh tinggi. Rata-rata effect size terendah dapat dilihat pada video, sebesar 0,26 dengan kategori rendah.

Tabel 6. Distribusi Karakteristik Berdasarkan Materi Pembelajaran

\begin{tabular}{|c|c|c|c|}
\hline Materi & $\begin{array}{c}\mathrm{N} \\
\text { (jumlah } \\
\text { artikel) }\end{array}$ & $\begin{array}{l}\text { Effect } \\
\text { Size }\end{array}$ & Kategori \\
\hline $\begin{array}{c}\text { Teori kinetik gas } \\
\text { dan termodinamika }\end{array}$ & 1 & 0,45 & Sedang \\
\hline $\begin{array}{l}\text { Dinamika rotasi dan } \\
\text { hukum Hooke }\end{array}$ & 1 & 1,35 & $\begin{array}{l}\text { Sangat } \\
\text { Tinggi }\end{array}$ \\
\hline $\begin{array}{l}\text { Gerak parabola dan } \\
\text { gerak melingkar }\end{array}$ & 1 & 1,03 & Tinggi \\
\hline $\begin{array}{l}\text { Momentum, } \\
\text { impuls, dan getaran } \\
\text { harmonis sederhana }\end{array}$ & 1 & 1,78 & $\begin{array}{l}\text { Sangat } \\
\text { Tinggi }\end{array}$ \\
\hline $\begin{array}{l}\text { Gerak parabola, } \\
\text { gerak melingkar, } \\
\text { dan hukum Newton }\end{array}$ & 1 & 3,29 & $\begin{array}{l}\text { Sangat } \\
\text { Tinggi }\end{array}$ \\
\hline Fluida statis & 1 & 0,30 & Rendah \\
\hline Optik geometri & 1 & 0,97 & Tinggi \\
\hline Suhu dan kalor & 1 & 1,05 & Tinggi \\
\hline Listrik dinamis & 1 & 1,90 & $\begin{array}{l}\text { Sangat } \\
\text { Tinggi }\end{array}$ \\
\hline
\end{tabular}

Dari tabel 6, effect size tertinggi adalah pada materi gerak parabola, gerak melingkar, dan hukum Newton, yaitu sebesar 3,29 dengan kategori berpengaruh tinggi. Sedangkan effect size terendah pada materi fluida statis 0,30 kategori rendah.

Tabel 7. Distribusi Karakteristik Berdasarkan Unit Metode / Strategi / Pendekatan

\begin{tabular}{cccc}
\hline Metode / & $\mathrm{N}$ & $\begin{array}{c}\text { Effect } \\
\text { Size }\end{array}$ & Kategori \\
Strategi / & Artikel & & \\
Pendekatan / & & & \\
Model & & & \\
\hline Model PBL & 4 & 1,285 & Tinggi \\
Model Inkuiri & 2 & 0,88 & Tinggi \\
Model & 1 & 1,19 & Sangat \\
Learning Cycle & & & Tinggi \\
3E & & & \\
Model CTL & 1 & 0,38 & Rendah \\
Model & 1 & 0,26 & Rendah \\
Discovery & & & \\
Model CUPs & 1 & 0,45 & Sedang \\
Model & 1 & 0,60 & Sedang \\
Penalaran & & & \\
Kausal & & & Tinggi \\
Pendekatan & 2 & 1,265 & \\
Saintifik & & &
\end{tabular}




\begin{tabular}{cccc}
\hline Metode / & $\mathrm{N}$ & $\begin{array}{c}\text { Effect } \\
\text { Strategi / }\end{array}$ & Kategori \\
$\begin{array}{c}\text { Pendekatan / } \\
\text { Model }\end{array}$ & & & \\
\hline $\begin{array}{c}\text { Pendekatan } \\
\text { Deduktif \& }\end{array}$ & 1 & 0,87 & Tinggi \\
Induktif & & & \\
Strategi & 1 & 2,19 & $\begin{array}{c}\text { Sangat } \\
\text { Tinggi }\end{array}$ \\
Student Recap & & & \\
\hline
\end{tabular}

Dari tabel 7 didapatkan bahwa, effect size tertinggi adalah pada strategi student recap, yaitu sebesar 2,19 dengan kategori berpengaruh tinggi. Sedangkan effect size terendah adalah model discovery, yaitu sebesar 0,26 dengan kategori rendah.

\section{Pembahasan}

Berdasarkan hasil penelitian yang telah dilakukan mengenai pengaruh bahan ajar fisika terhadap hasil belajar siswa, yaitu terdiri dari 25 artikel yang digunakan dapat ditinjau berdasarkan tingkatan jenjang pendidikan, tingkatan kelas, jenis bahan ajar, materi pembelajaran, unit metode / strategi / pendekatan / model.

Pertama, ditinjau berdasarkan tingkatan jenjang pendidikan, maka dapat dilihat dari tabel 3, effect size yang sangat tinggi yaitu sebesar 1,395 pada jenjang pendidikan SMP. Dapat dilihat bahwa sannya jenjang pendidikan SMP lebih berpengaruh daripada jenjang pendidikan SMA maupun SMK. Hal ini membuktikan bahwa penerapan bahan ajar fisika yang bermuatan karakter, materi pembelajarannya lebih mudah dipahami oleh siswa SMP karena siswa memiliki panduan yang dapat dicocokkan dengan materi pembelajaran yang dijelaskan oleh guru di depan kelas. Bahan ajar fisika yang bermuatan karakter dapat membantu siswa dalam membuat catatan yang bisa dikreasikan sendiri oleh siswa, dimana catatan tersebut dapat berupa mind map. Pendapat tersebut sejalan dengan Anggreini, A. (2013) yang menyatakan bahwa bahan ajar fisika sangat berpengaruh terhadap hasil belajar siswa dengan menggunakan nilai karakter pada setiap ranah kognitif, psikomotor, dan afektif.

Kedua, ditinjau berdasarkan tingkatan kelas, maka dapat dilihat dari tabel 4, effect size yang sangat tinggi yaitu sebesar 1,395 (kelas VIII) dan 1,19 (kelas X). Jika dipilih yang paling tinggi, maka didapatkan pada tingkatan kelas VIII. Dapat dilihat bahwa tingkatan kelas VIII lebih berpengaruh daripada tingkatan kelas lainnya.

Ketiga, ditinjau berdasarkan jenis bahan ajar, maka dapat dilihat dari tabel 5, effect size yang sangat tinggi yaitu sebesar 1,418 pada bahan ajar. Bahan ajar ini terdiri dari 15 artikel yang telah di analisis. Bahan ajar memiliki pengaruh yang lebih tinggi daripada LKPD, modul, ataupun video. Hal ini membuktikan bahwa bahan ajar yang menggunakan strategi, pendekatan, metode, maupun model dapat meningkatkan hasil belajar, pemahaman konsep, dan lain sebagainya. Hal ini didukung oleh Basviani, L. N. (2014) yang mengatakan bahwa bahan ajar fisika membawa pengaruh yang positif dalam kegiatan belajar siswa yang ditunjukkan dengan tingginya pencapaian hasil belajar siswa. Hasil belajar yang diperoleh dari kelas eksperimen berbedabeda signifikan dibandingkan kelas kontrol. Hal ini berarti bahan ajar fisika dalam pembelajaran dapat meningkatkan hasil belajar siswa.

Keempat, ditinjau berdasarkan materi pembelajaran, maka dapat dilihat dari tabel 6 , effect size yang berpengaruh tinggi yaitu sebesar 3,29 pada materi gerak parabola, gerak melingkar, dan hukum Newton. Hal ini membuktikan bahwa materi gerak parabola, gerak melingkar, dan hukum Newton lebih mudah dimengerti oleh siswa menggunakan strategi daripada menggunakan model, metode, ataupun pendekatan. Hal ini didukung oleh Khairunnisa, H., \& Kamus, Z. (2018) yang menyatakan bahwa bahan ajar fisika yang menggunakan materi yang 
mengandung nilai konten nilai kecerdasan sosial pada materi gerak parabola, gerak melingkar, dan hukum Newton terlihat meningkatnya aspek pengetahuan setelah menggunakan bahan ajar fisika tersebut. Hal ini membuktikan bahwa bahan ajar fisika dapat meningkatkan hasil belajar dari peserta didik.

Terakhir ditinjau berdasarkan unit metode / model / strategi / pendekatan, maka dapat dilihat dari tabel 7 , effect size yang berpengaruh tinggi yaitu sebesar 2,19 pada strategi yang disebut dengan strategi student recap. Hal ini membuktikan bahwa siswa lebih mengerti pembelajaran yang menggunakan bahan ajar dengan strategi yaitu strategi student recap daripada yang menggunakan model, metode, maupun pendekatan. Dan juga hasil belajar siswa mengalami peningkatan dengan menggunakan strategi student recap. Hal ini sejalan dengan pernyataan Utari, M. S. (2014) yang menyatakan bahwa bahan ajar fisika berbasis karakater menggunakan strategi student recap memberikan dampak yang signifikan terhadap hasil belajar siswa yang terlihat dari perbandingan kelas eksperimen yang menggunakan student recap baik pada ranah kognitif, psikomotor dan afektif dibandingkan dengan kelas kontrol yang menggunakan bahan ajar fisika yang sudah disediakan guru.

Dilihat dari jenjang pendidikan, tingkatan kelas, materi pembelajaran, dan lain sebagainya, didapatkan hasil analisa bahwa diantara beberapa effect size yang sangat tinggi, maka pada artikel ke-13 atau disebut dengan M13 yaitu sebesar 3,29. Artikel M13 ini, bahan ajar yang memiliki pengaruh yang lebih tinggi dibandingkan dengan yang lain. Artikel ini mengenai analisis efektivitas pengembangan bahan ajar fisika dengan konten kecerdasan sosial pada materi gerak parabola, gerak melingkar, dan hukum Newton untuk kelas X SMA. Hal ini membuktikan bahwa bahan ajar dengan konten nilai-nilai kecerdasan sosial sudah sesuai dengan struktur-struktur bahan ajar yang semestinya dan efektif digunakan untuk pembelajaran karena dapat meningkatkan aspek pengetahuan siswa.

\section{PENUTUP}

Berdasarkan hasil dan pembahasan yang telah dipaparkan diatas, dapat disimpulkan bahwa bahan ajar memiliki pengaruh yang tinggi terhadap hasil belajar siswa, terutama pada pembelajaran fisika. Karena bahan ajar merupakan salah satu pendukung siswa dalam proses pembelajaran. Pada hasil analisis data yang dilakukan bahwa kombinasi bahan ajar fisika dengan hasil belajar siswa menghasilkan effect size 1,1308 dengan kategori tinggi. Jadi, bahan ajar fisika memiliki pengaruh yang besar terhadap proses pembelajaran siswa dan hasil belajar siswa.

\section{REFERENSI}

Aflah, M., \& Kamus, Z. (2019). Pengaruh Penggunaan Bahan Ajar Fisika Terintegrasi Konten Nilai Kecerdasan Sosial Pada Materi Gerak Parabola Dan Gerak Melingkar Terhadap Pencapaian Kompetensi Siswa Kelas X SMA 13 Padang. Pillar Of Physics Education, 12(2). DOI: https://dx.doi.org/10.24036/4909171074

Andi, F. S., Darvina, Y., \& Ratnawulan, R. (2017). Pengaruh Penggunaan Bahan Ajar Non Cetak Bermuatan Karakter Menggunakan Pendekatan Saintifik Terhadap Kompetensi Siswa Pada Materi Gelombang Mekanik Kelas XI SMA Negeri 3 Padang. Pillar Of Physics Education, 10(1).

Anggreini, A. (2013). Pengaruh Penerapan Bahan Ajar Fisika Bermuatan Nilai Nilai Karakter Pada Konsep Listrik Dinamis Dalam Pembelajaran Kooperatif Tipe Stad Terhadap Hasil Belajar Siswa Kelas X SMA N 4 
Padang. Pillar Of Physics Education, 2(1).

DOI:

https://dx.doi.org/10.24036/728171074

Astiti, K. A., \& Yusuf, Y. H. M. (2018). Pengaruh Penggunaan Bahan Ajar Berbasis Kontekstual Terhadap Peningkatan Pemahaman Konsep Fisika Siswa Materi Suhu Dan Kalor. Jurnal Fisika: Fisika Sains Dan Aplikasinya, 3(2), 185-192. DOI: https://doi.org/10.35508/fisa.v3i2.625

Aulia, F., Djamas, D., \& Ramli, R. (2017). Pengaruh Modul Fisika Multimedia Interaktif Berbantuan Game Dalam Model Problem Based Learning Terhadap Critical Thinking Skill Siswa Kelas X SMAN 4 Padang. Pillar Of Physics Education, 9(1). DOI:

https://dx.doi.org/10.24036/2517171074

Basviani, L. N. (2014). Pengaruh Penerapan Bahan Ajar Fisika Terintegrasi Nilai Karakter dalam Model Learning Cycle 7E terhadap Hasil Belajar Siswa Kelas XI di SMAN 4 Bukittinggi. Pillar of Physics Education, 3(1). DOI: https://dx.doi.org/10.24036/1924171074

Diani, R. (2016). Pengaruh pendekatan saintifik berbantukan LKS terhadap hasil belajar fisika peserta didik Kelas XI SMA Perintis 1 Bandar Lampung. Jurnal Ilmiah Pendidikan Fisika AlBiruni, 5(1), 83-93.

Ertikanto, C., \& Rosidin, U. (2019). Pengaruh Penggunaan Modul Pembelajaran Kontekstual Berbasis Multiple Representations Pada Materi Fluida Statis Terhadap Kemampuan Berpikir Kritis Siswa. Jurnal Pendidikan Fisika, 7(2), 265-278.

Glass, G.V., McGaw B., \& Smith, M.L. (1981). Meta-Analysis in Social Research. London: Sage Publications.

Hadiwijaya, A. S. (2015). Pengembangan Bahan Ajar Fisika SMA Berbasis Learning Cycle (LC) 3E Pada Materi Pokok Teori Kinetik Gas dan Termodinamika. Jurnal Penelitian Pendidikan IPA, 1(1).
Hakim, S., Wahyudi, W., \& Verawati, N. N. S. P. (2018). Pengaruh Model Pembelajaran Contextual Teaching and Learning (CTL) Berbantuan LKS terhadap Hasil Belajar Fisika Siswa SMA Attohiriyah Bodak. Lensa: Jurnal Kependidikan Fisika, 6(1), 1-7. DOI: $\quad$ https://doi.org/10.33394/j$\underline{\text { lkf.v6i1.929 }}$

Hasibuan, N. S., \& Hufri, H. (2018). Pengaruh Bahan Ajar Fisika Berbasis Inkuiri untuk Meningkatkan Kemampuan Berpikir Kreatif Peserta Didik pada Materi Momentum, Impuls dan Getaran Harmonik Sederhana Kelas X SMAN 8 Padang. Pillar of Physics Education, 11(3), 97-104. DOI:

https://dx.doi.org/10.240363761171074

Hidayat, K., Kade, A., \& Haeruddin, H. (2014). Pengaruh Model Pembelajaran Berbasis Masalah (PBM) menggunakan bahan ajar berbasis EMateri terhadap pemahaman konsep fisika pada siswa kelas X SMAN 1 Biromaru. JPFT (Jurnal Pendidikan Fisika Tadulako Online), 1(3), 23-31.

Herlina, L. (2019). Pengaruh Bahan Ajar Fisika Berbasis Kontruktivis dengan Pembelajaran Inkuiri pada Materi Dinamika Rotasi dan Hukum Hooke untuk Meningkatkan Literasi Sains Siswa Kelas XI SMAN 1 V Koto Kampung Dalam (Doctoral dissertation, Universitas Negeri Padang). DOI: https://dx.doi.org/10.24036/7426171074.

Ibrahim, I., Kosim, K., \& Gunawan, G. (2017). Pengaruh Model Pembelajaran Conceptual Understanding Procedures (CUPs) Berbantuan LKPD terhadap Kemampuan Pemecahan Masalah Fisika. Jurnal Pendidikan Fisika dan Teknologi, 3(1), 14-23. DOI: http://dx.doi.org/10.29303/jpft.v3i1.318

Islamiah, A. F., Rahayu, S., \& Verawati, N. N. S. P. (2018). Efektivitas Model Pembelajaran Problem Based Learning Berbantuan Lks Terhadap Kemampuan Berpikir Kritis Fisika 
Siswa Sman 1 Lingsar Tahun Ajaran 2016/2017. Lensa: Jurnal Kependidikan Fisika, 6(1), 29-36. DOI: $\quad$ https://doi.org/10.33394/j$\underline{\text { kf.v6i1.933. }}$

Kamus, Z., \& Afrizon, R. (2019). Pengaruh Penggunaan Bahan Ajar Fisika Terintegrasi Kecerdasan Sosial Melalui Model Pembelajaran Berbasis Masalah Terhadap Pencapaian Kompetensi Peserta Didik Kelas X SMAN 16 Padang. Pillar Of Physics Education, 12(1).

Khairunnisa, H., \& Kamus, Z. (2018). Analisis Efektivitas Pengembangan Bahan Ajar Fisika dengan Konten Kecerdasan Sosial pada Materi Gerak Parabola, Gerak Melingkar dan Hukum Newton untuk Kelas X SMA. Pillar of Physics Education, 11(2), 121-128.

DOI: https://dx.doi.org/10.24036/3095171074.

Liskaningsih, A., Gummah, S., \& Wardani, I. K. (2016). Perbedaan Hasil Belajar Fisika Siswa yang Menggunakan LKS Berorientasi pada Kemampuan Berpikir Induktif dengan Kemampuan Berpikir Deduktif. Lensa: Jurnal Kependidikan Fisika, 4(2), 59-61.

Mahardika, N., Akmam, A., \& Gusnedi, G. (2016). Pengaruh Penerapan Bahan Ajar Bermuatan Kecerdasan Komprehensif Menggunakan Model Pembelajaran Inkuiri Terhadap Komptensi Fisika Siswa Kelas X Sman 4 Padang. Pillar of Physics Education, $\quad 7(1)$. DOI: https://dx.doi.org/10.24036/1999171074.

Muslimin, S., Rafiqah, R., \& Ikbal, M. S. I. (2018). Pengembangan Lembar Kerja Peserta Didik Berbasis Etnosains Dengan Model Penalaran Kausal Untuk Memecahkan Masalah. Jurnal Pendidikan Fisika, 6(1), 8-18.

Oktaviani, W., Gunawan, G., \& Sutrio, S. (2017). Pengembangan Bahan Ajar Fisika Kontekstual Untuk Meningkatkan Penguasaan Konsep Siswa. Jurnal Pendidikan Fisika dan
Teknologi, 3(1), 1-7. DOI: https://dx.doi.org/10.29303/jpft.v3i1.320

Pratiwi, W., Darmadi, I. W., \& Muslimin, M. Pengaruh Model Pembelajaran Discovery Berbantuan Media Video Pembelajaran Fisika Terhadap Keterampilan Berpikir Kreatif Siswa di SMA Negeri 4 Palu. JPFT (Jurnal Pendidikan Fisika Tadulako Online), 5(1), 41-44.

Sutrisno, L. (2007). Pengaruh Problem Based Learning Pada Hasil Belajar Fisika: Sebuah Meta-Analisis Artikel Jurnal Online Indonesia. Jurnal Pendidikan dan Pembelajaran Khatulistiwa, 6(3).

Tamami, F., Rokhmat, J., \& Gunada, I. W. (2017). Pengaruh Pendekatan Berpikir Kausalitik Scaffolding Tipe 2a Modifikasi Berbantuan LKS Terhadap Kemampuan Pemecahan Masalah Optik Geometri Dan Kreativitas Siswa Kelas XI SMAN 1 Mataram. Jurnal Pendidikan Fisika dan Teknologi, 3(1), 76-83. DOI: https://dx.doi.org/10.29303/jpft.v3i1.333

Utari, M. S. (2014). Pengaruh Penerapan Bahan Ajar Fisika Bermuatan Karakter dalam Strategi Pembelajaran Student Recap terhadap Hasil Belajar Siswa Kelas VIII SMPN 12 Padang. Pillar Of Physics Education, 4(2). DOI:

https://dx.doi.org.10.24036/1888171074

Yenni, R. P., Masril, M., \& Hidayati, H. (2016). Pengaruh Penerapan Bahan Ajar Berbasis Pendekatan Saintifik Melalui ICT Dalam Model Pembelajaran Inquiry Terhadap Kompetensi Fisika Siswa Kelas X SMA N 1 Padang. Pillar Of Physics Education, 7(1). DOI: https://dx.doi.org/10.24036/1983171074 